\title{
ELECTRICAL STIMULATION OF SACCHAROMYCES CEREVISIAE CULTURES
}

\author{
Ofelia Q.F. Araújo*; Maria Alice Z. Coelho; Isabel C.P. Margarit; Carlos A. Vaz-Junior; \\ Maria Helena M. Rocha-Leão
}

Universidade Federal do Rio de Janeiro, Escola de Química, Centro de Tecnologia, Rio de Janeiro, RJ, Brasil.

Submitted: July 28, 2003; Returned to authors: March 04, 2004; Approved: May 20, 2004.

\begin{abstract}
Modulation of cell endogenous membrane potential by an external electrical field influences the structure and function of membrane compartments, proteins and lipid bi-layer. In this work, the effects of applied potential on Saccharomyces cerevisiae growth were characterized through simple yet conclusive experiments. Cell growth time profile and cell division were investigated as macroscopic response to the electrical stimulation. Control experiments were conducted under identical conditions except for the absence of applied potential. Through comparative analysis, electrical stimulation was verified to alter cell cycle as smaller sized population was observed, suggesting that a synchrony in cell division was promoted. Power spectral analysis was employed to sustain synchrony enhancement, and mathematical modeling was conducted for determining kinetic growth changes. Monod type kinetic parameters for growth were determined by non-linear regression. The affinity constant (namely $\mathrm{k}_{\mathrm{s}}$ ) presented a dependence on applied potential suggesting changes on transport across cell membrane. Electrochemically promoted stress was also verified to inhibit growth as well as to induce changes on cell viability.
\end{abstract}

Key words: electrochemical stress, Saccharomyces cerevisiae, cell cycle, viability

\section{INTRODUCTION}

Responses of living cells and biochemicals to electrical signals have been used, for example, in biotechnology (1), bioanalytical techniques $(7,9,12)$ and medical purposes $(6)$. Depending on the intensity of the applied electrical potential and on its time function (constant, pulsed, etc), distinct effects in metabolic processes may occur. Such exogenous stimulation determines the appearance of an electric potential across the membrane which depends on the strength of the external field, cell shape, cell radius and membrane properties. The modulation of the endogenous membrane potential by an external field influences the structure and function of the membrane compartments, proteins and lipid bilayer (8). Additionally, Binninger et al. (4) have observed that the abundance of specific messenger RNAs (mRNAs) was altered in yeast cells - a unicellular organism that has been used as a model by molecular biologists - following exposure to magnetic field.
Satroutdinov et al. (17) report short period (40-50 min) oscillation in continuous aerobic synchronized metabolic culture of Saccharomyces cerevisiae. In glucose-limited cultures of $S$. cerevisae, oscillation can be associated to a partial synchronization of the culture. According to Hjortso and Nielsen (11), the cell metabolism responds to changes in environmental conditions in such a way that the age at division and age at transition changes periodically with the same period as the changes in the medium. The periodic changes in division and transition ages result in an attractor among the cells which stabilizes or enhances the initial synchrony.

Among the several types of stress reported in literature, thermal stress is the most widely studied. All stress forms promote similar cell responses although their working mechanism could be distinct. The interaction between two different types of stresses (cross protection) may allow the development of interesting industrial and pharmaceutical applications. It was shown that thermal treatment of $S$.

*Corresponding author. Mailing address: Escola de Química, UFRJ, Centro de Tecnologia, B1. E, Lab. 113, Cidade Universitária. 21949-900, Rio de Janeiro, RJ, Brasil. E-mail: ofelia@eq.ufrj.br 
cerevisiae results in an increased tolerance to ethanol which points out to industrial use of induced cell stress. It is important to note that electric field promoted stress, herein defined as electrochemical stress, once verified to occur, presents industrial advantages over other types of stress as no addition of external chemicals which would otherwise increase product separation and waste treatment costs. In relation to thermal stress, electrochemically promoted stress presents favorable dynamics, as no significant inertial phenomenon is presented.

The main purpose of the present work is to characterize the effects of applied electrochemical potential on Saccharomyces cerevisiae growth. While it has already been shown that potential/current can affect the growth of microorganisms in a culture by (re)generation of metabolites/catabolites $(3,14,15)$, to our knowledge, this is the first attempt to demonstrate that applied potential interferes with oscillations, cell cycle and stress responses of Saccharomyces cerevisae.

\section{MATERIALS AND METHODS}

\section{Yeast strain and medium}

Saccharomyces cerevisiae S288C (ATCC 26108, $\alpha$ GLC mal gal 2), gently provided by Dr. A.Panek, was used in this work and was preserved at $4^{\circ} \mathrm{C}$ in YPD agar medium. Inocula were grown at $28^{\circ} \mathrm{C}$ with agitation $(160 \mathrm{rpm})$ in YPD $(1 \%$ yeast extract, $2 \%$ peptone and $2 \%$ glucose) up to $3.3 \mathrm{mg} \mathrm{d} . \mathrm{w} . / \mathrm{mL}$.

Electrochemical stability of the main energy source (glucose) was investigated by steady-state voltametry at $50 \mathrm{mV} / \mathrm{s}$ in the potential range -0.8 VSCE to +1.0 VSCE. Experimental set-up for voltametry consisted of a Radiometer Voltalab 40 apparatus connected to a classic three-electrode cell, with a platinum disk $\left(0.23 \mathrm{~cm}^{2}\right)$ as working electrode (WE), a platinum grid as auxiliary electrode (AE) and saturated calomel electrode (SCE) as reference. Steady state polarization curves were also obtained in order to better characterize the electrochemical processes occurring in the bioelectrochemical reactor during potentiostatically controlled culture growth.

\section{Batch cultivation}

$S$. cerevisiae $\mathrm{S} 288 \mathrm{C}$ previously grown were reinoculated in modified YPD medium $(0.64 \%$ peptone, $1 \%$ yeast extract, $2 \%$ glucose, conductivity $1.74 \mathrm{mS} / \mathrm{cm}$ and $\mathrm{pH}=6.5$ ) in order to obtain an initial cell concentration around $0.2 \mathrm{mg} \mathrm{d.w./mL} \mathrm{and}$ introduced into the bioelectrochemical reactors - acrylic vessels, each with $300 \mathrm{~mL}$ total volume, divided in two chambers. All chambers were provided with holes on the top for mounting electrodes, thermometers, air uptake and sampling. AE and WE consisted of platinum grids. SCEs were used as references. AE and WE chambers were separated by nitrocellulose membranes to isolate microorganisms submitted to the different redox regions of the polarized electrodes. All experiments were conducted with forced aeration through sintered diffusers placed at the bottom of the vessels. The maintenance of microorganisms in suspension was guaranteed by the aeration method employed, avoiding the use of magnetic stirring, which would interact with the applied electric field, and has also been pointed out as stress agent (10). Potentiostats Omnimetra were employed to control potentials during experiments.

Oxygen saturation was guaranteed during all experiments. Dissolved oxygen concentration in bioelectrochemical reactors was monitored (DIGIMED DMO-2). Neither differences on $\mathrm{O}_{2}$ content were detected between polarized and negative control experiment (i.e. no potential applied), nor significant changes in $\mathrm{pH}$ could be recorded. At the end of each experiment, $\mathrm{pH}$ values were about 6.5 in the WE chambers. Room temperature and $28^{\circ} \mathrm{C}$ thermostatic experiments were carried.

\section{Potential Application}

Potential was applied to the culture in three different conditions: i) since the inoculation time; ii) at the beginning of the transition phase, i.e., when half of initial glucose concentration is attained $\left(\mathrm{S}_{0} / 2\right)$; and iii) in rectangular pulsed potential starting at the inoculation time, 1 hour of potential application was followed with one hour of open-circuit, and the cycle was kept until the end of experimental run.

The value of applied potential was $0.75 \mathrm{~V}_{\mathrm{SCE}}$ based on the work of $\mathrm{Ci}$ et al. (7), who related peak currents at this potential with viability of $S$. cerevisiae. The open-circuit potential of platinum in the culture medium was about $+0.25 \mathrm{~V}_{\mathrm{SCE}}$ thus experiments were conducted with $0.5 \mathrm{~V}$ anodic overpotential.

In all experimental runs, a control reactor was employed (no potential was applied, i.e., a negative-control). Cell optical density in WE compartments were measured with a spectrophotometer $(570 \mathrm{~nm})$, with a $10 \mathrm{~min}$ sampling period, and converted to cell concentration through dry weight correlation. Glycogen and glucose were analyzed in a 30 minutes sampling interval. Glucose was measured by glucose oxidase (16) and glycogen determination followed method presented in Becker (2).

\section{Cell viability and oscillation}

Cell classification was conducted as the number of nonviable cells (with methylene blue), budding-cells and total cells (viable and non-viable), measured with the aid of a Newbauer chamber (5) in an optic microscope (Nikon Elipse E200, 400x magnification). All experiments were carried at least in triplicate and the respective analysis were conducted in duplicate.

Oscillations were investigated through the power spectra of cell concentration profiles. No prior treatment to remove trends was applied since such procedure could remove important information referring to oscillations. A Hamming window with width $\gamma=10$ was used. The frequency resolution achieved is inversely proportional to the window width $(=\pi /(\gamma . \sqrt{2}) \mathrm{rad} /$ time unit). Therefore, details in the true frequency function that is finer than the frequency resolution is smeared out in the 
estimate. However, decreasing frequency resolution brings the benefit of decreasing the high variability presented by periodograms.

In power spectra estimated, as sampling time $\left(\mathrm{T}_{\mathrm{s}}\right)$ was $10 \mathrm{~min}$, the limit frequency that can be captured by power spectra analysis is of $(\sim 0.3 \mathrm{rad} / \mathrm{min})$. Hence, frequency window of interest is $\sim 0.05-0.3 \mathrm{rad} / \mathrm{min}$.

\section{RESULTS AND DISCUSSION}

\section{Voltamograms}

Steady-state voltamograms were performed in order to evaluate the eletrochemical stability of the YPD medium, i.e. in what range the medium was eletrochemically stable. The obtained voltamograms are shown in Fig. 1. No reaction involving glucose electrochemical reactions was detected in the whole voltamogram for three different glucose contents $(2 \%, 10 \%$ and $20 \% \mathrm{w} / \mathrm{v})$, attesting the stability of the main energy source at this potential range.

Additionally, it can be seen that the potential herein applied, +0.75 VSCE, is within the water stability zone. The voltamograms peaks observed in Fig. 1 are due to water decomposition (higher potential) and reduction of dissolved oxygen (lower potential). Thus, important changes on $\mathrm{pH}$ are avoided during $S$. cerevisiae potentiostatically controlled growth at that potential.

\section{Culture absorbance}

Oscillation on culture absorbance was observed (Fig. 2). As total number of cells (budded, non-budded and non-viable cells) does not decrease, absorbance could only be altered by cell size distribution in the yeast population. It should be noticed that the reported oscillation in growth profiles was not a random experimental error, or white noise. A white noise would by

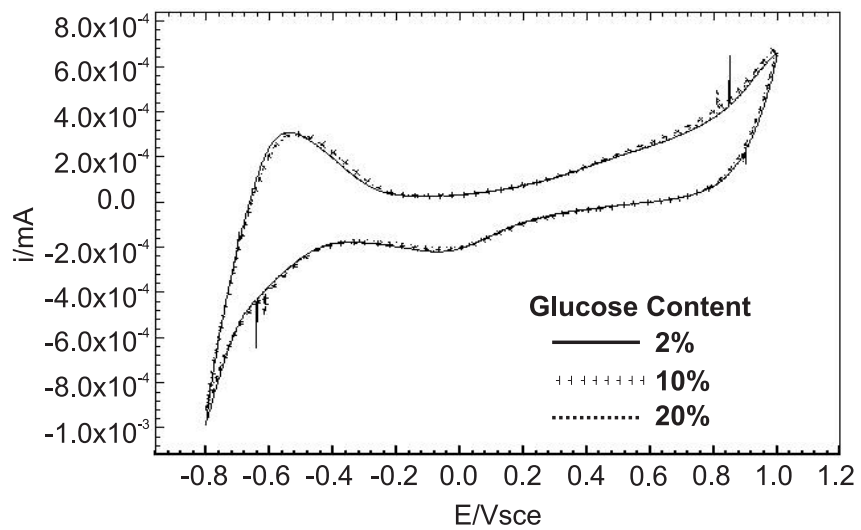

Figure 1. Cyclic voltametry of YPD medium with different glucose concentrations (scan rate of $50 \mathrm{mV} \cdot \mathrm{s}^{-1}$ ). definition present a zero average and would have a constant power spectral density ( $=\sigma^{2}$, the white noise variance). In the cases above studied, the respective power spectrum obtained provided well defined frequency contributions as described next, in the power spectra analysis. Additionally, observation of cells using an optical microscope indicated smaller cell size in culture with pulsing applied potential as compared to control experiments.

\section{Power spectra}

Spectra of growth data (absorbance measured at $10 \mathrm{~min}$. period) were displayed in Fig. 2. The sequence of figures showed the differences obtained in frequency domain along batch time which considers the influences of the stage of the cell growth in each frequency. So, the initial spectrum was plotted with 25 data points obtained till $4.7 \mathrm{~h}$ process showed peaks at four specific frequencies: $0.07 \mathrm{rad} / \mathrm{min}, 0.14 \mathrm{rad} / \mathrm{min}, 0.20 \mathrm{rad} / \mathrm{min}$ and $0.25 \mathrm{rad} / \mathrm{min}$, that corresponded to periods of $90 \mathrm{~min}, 45$ min, $30 \mathrm{~min}$ and $25 \mathrm{~min}$, respectively. As acquired points were added, one-by-one along growth profiles (6h, $7.8 \mathrm{~h}$ and $9.7 \mathrm{~h}$ process), spectra presented sustained peak amplitudes up to "turn points" where new thresholds are reached, corresponding to growth phase changes.

The influence of potential application time on power spectra was also investigated (Fig. 2). A relevant difference can be noticed at $0.07 \mathrm{rad} / \mathrm{min}$ (90 min time constant): all applied potential presented broader peaks (reduced amplitude and enlarged frequency window) at process time between 6 to $7.8 \mathrm{~h}$ Nevertheless, at $\mathrm{t}=9.7 \mathrm{~h}$, the growth frequency spectrum for cells submitted to potential applied at $S_{0} / 2$ presented a similar profile to that obtained for the control system (no potential applied) at $0.07 \mathrm{rad} / \mathrm{min}$ while the experiments relative to applied potential since inoculation time and pulsed potential retain the potential influence on such peak. These results demonstrate that $S$. cerevisiae electrical stimulation alters the contribuition of 90 min frequency in latter growth phases.

\section{Cell viability}

The impact of electrical field on cell division is expressive and is evidenced in the growth rate curve lumped in classes "budding", "non-budding" and non-viable cells. Fig. 3 displays results of cell characterization at different points along growth profile. At intermediate time (almost $6 \mathrm{~h}$ process), both applied potential experiments showed increase in budding cells. However, following an adaptation time, experiment with continuous time application (application instant at $\mathrm{S}_{0} / 2$ ) returns to similar cell distribution situation presented by the control experiment, while pulsed potential continuously increases budding cell percentage. Results suggest the interference of electrical potential on cell cycle. Furthermore, the observed broader frequency band at $0.07 \mathrm{rads} / \mathrm{min}$ could be related to potential alteration of time to division. 

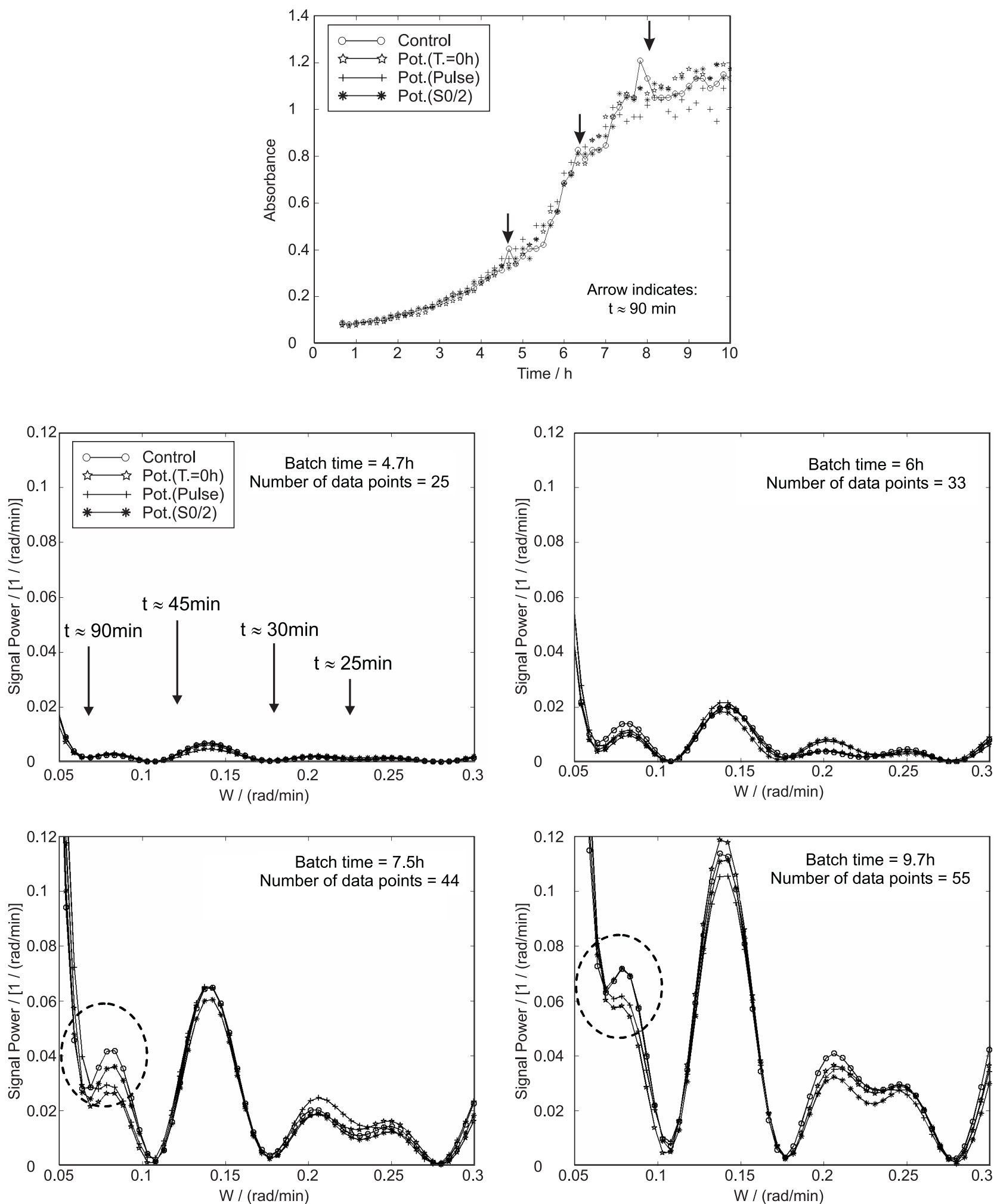

Figure 2. Growth profiles for control experiments (without potential) and experiments carried under continuous potential since the inoculation time $(\mathrm{t}=0 \mathrm{~h})$, at the beginning of the transition phase $\left(\mathrm{S}_{0} / 2\right)$ and under rectangular pulsed potential starting at the inoculation time. Respective spectral density along batch time $(\mathrm{t}=4.7,6,7.5,9.7 \mathrm{~h})$. 
When the period of exposure to electric potential is long, it is possible that cell reprogramming is reverted or attenuated to a considerable extent, i.e., concentrations of compatible solutes and Hsp suffer reduction and cells acquire tolerance. Readaptation could be claimed to force $0.07 \mathrm{rads} / \mathrm{min}$ peak relative to applied potential $\mathrm{S}_{0} / 2$ back to the behavior presented by the control experiment. This observation is in agreement with results obtained at pulsed potential, or "discontinuous stress". Cells are successively auto-reprogrammed and, therefore, stress control parameters are more expressive, and sensed at each pulse.

Higher frequency peaks (periods of 40, 30 and $25 \mathrm{~min}$ ) are not directly related to cell cycle but rather to cyclic behavior on respiration rate, glycogen concentration, ATP, NADH, observed by Stroutdinov et al. (17), probably induced by synchronized populations.

Furthermore, "synchrony in S. cerevisiae has been reported several times to start after small substrate pulses, shifts of dilution rate, $\mathrm{pH}$, aeration or other disturbances of asynchronous cultures" (13). Presently reported results suggest that applied potential is able to trigger on or off cell cycle activity and, thus, force cell synchrony. In this sense, pulsed potential (or discontinuous electrochemical stress) promotes more severe changes on cell cycle, as shown on Fig. 3. Mechanisms responsible for this biological response are yet to be investigated. It is possible that, concomitantly, a reduction in maturation time and cell volume occurs. Alternatively, it may be proposed that acceleration of signal transduction paths that conduct cell to "start point" in cell cycle may be taking place.

\section{A simple mathematical model}

A simple non-structured non-segregated mathematical model was employed to evaluate the impact of potential application on Monod-type kinetic terms:

$$
\begin{aligned}
& \frac{\mathrm{dX}}{\mathrm{dt}}=\frac{\mu_{\max } \cdot \mathrm{S}}{\mathrm{K}_{\mathrm{S}}+\mathrm{S}} \cdot \mathrm{X} \\
& \frac{\mathrm{dS}}{\mathrm{dt}}=-\frac{1}{\mathrm{Y}_{\mathrm{X} / \mathrm{S}}} \cdot \frac{\mu_{\max } \cdot \mathrm{S}}{\mathrm{K}_{\mathrm{S}}+\mathrm{S}} \cdot \mathrm{X}-\mathrm{m}_{\mathrm{S}} \cdot \mathrm{X}
\end{aligned}
$$

where $\mathrm{X}(\mathrm{t})$ is total biomass concentration $\left[\mathrm{mg} \cdot \mathrm{mL}^{-1}\right]$ and $\mathrm{S}(\mathrm{t})$ is substrate concentration (glucose) [mg.mL $\mathrm{mL}^{-1}$.

This model includes 4 parameters: a) maximum specific growth rate, $\mu_{\max }\left[\mathrm{h}^{-1}\right]$; b) affinity constant, $\mathrm{K}_{\mathrm{S}}\left[\mathrm{mg} \cdot \mathrm{mL}^{-1}\right]$, which is related to substrate transport from the growth medium to cell interior; c) conversion factor, $\mathrm{Y}_{\mathrm{X} / \mathrm{S}}\left[\mathrm{mg} \mathrm{S} .(\mathrm{mg} \mathrm{X})^{-1}\right]$, the amount of consumed substrate converted to biomass; d) maintenance constant, $\mathrm{m}_{\mathrm{S}}$ [mg S.(mg X.h $)^{-1}$, representing the amount of substrate consumed in order to maintain cell viability, set to

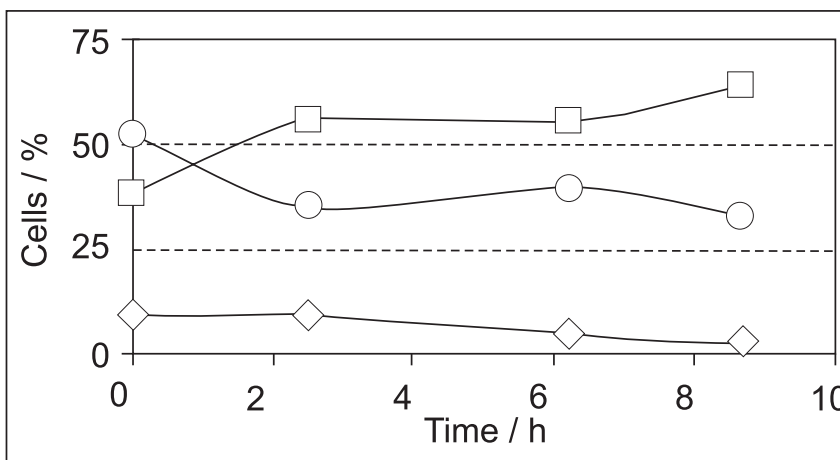

(A)

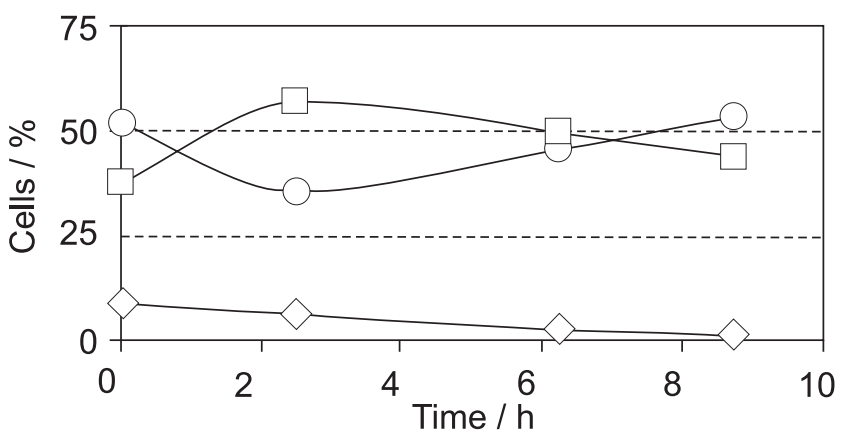

(B)

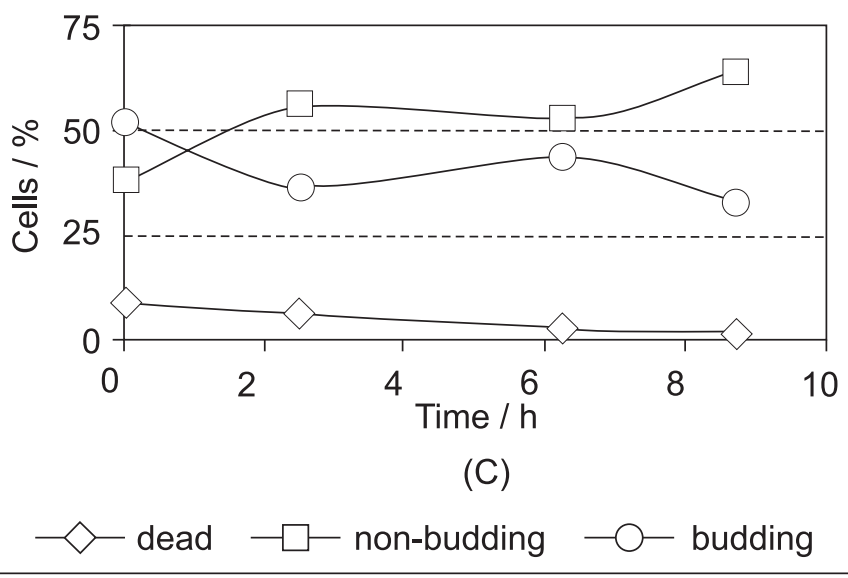

Figure 3. Potential effect on cell viability and reproduction through measurements in a Newbauer chamber with methylene blue. (a) Control (no-applied potential), (b) Pulsed Potential (rectangular pulse: $0.75 \mathrm{~V}$ applied at $\mathrm{t}=0 \mathrm{~h}$ with duration of $1 \mathrm{~h}$, followed by another $1 \mathrm{~h}$ with no-applied potential; pattern is repeated up to final time), (c) Constant Potential (applied at $\mathrm{S}_{0} / 2$ ).

0.01. An initial approach was to fit the model to each individual potential data set. Results presented approximately constant values for $\mu_{\max }$ and $\mathrm{Y}_{\mathrm{X} / \mathrm{s}}$ while $\mathrm{K}_{\mathrm{S}}$ followed a parabolic function. Non-linear least-square was then employed to the entire data set, assuming a parabolic function for $\mathrm{K}_{\mathrm{S}}$ and results are displayed in Table 1. 
Munch et al. (13), based on experimental results, hypothesized that culture internal substrate shifts might be responsible for the existence of spontaneous synchronization in continuous yeast cultures. In the same direction, this work presents important parameter regression results leading to a dependence of the affinity constant on applied potential and suggesting that potential enhances transport across cell membrane as minimum $\mathrm{K}_{\mathrm{S}}$ corresponds to open-cell potential (Fig. 4).

Table 1. Estimated kinetic parameters of the Monod-type Model.

\begin{tabular}{cc}
\hline Parameter & Estimated Value \\
\hline$\mu_{\max }$ & 0.40 \\
\hline $\mathrm{Y}_{\mathrm{XS}}$ & 0.12 \\
\hline $\mathrm{K}_{\mathrm{S}}=\mathrm{a}_{1} \Phi^{2}+\mathrm{a}_{2} \Phi+\mathrm{a}_{3}$ & \\
$\mathrm{a}_{1}$ & 5.93 \\
$\mathrm{a}_{2}$ & 2.44 \\
$\mathrm{a}_{3}$ & 3.32 \\
\hline
\end{tabular}

$\Phi$ is applied potential (in $\mathrm{V}_{\mathrm{SCE}}$ ).

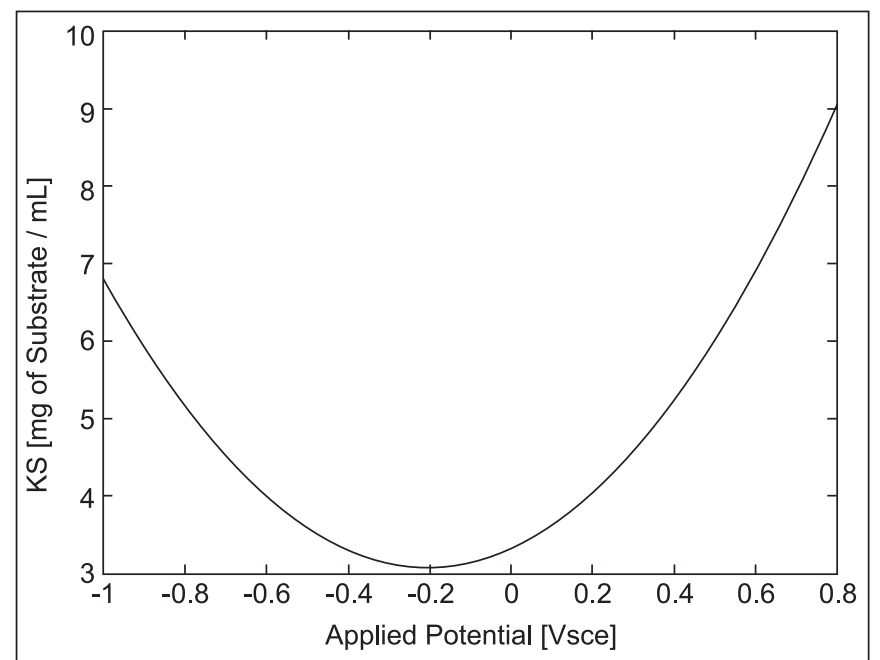

Figure 4. Affinity constant $\left(\mathrm{K}_{\mathrm{S}}\right)$ dependence on magnitude of the potential applied.

\section{CONCLUSIONS}

Simple yet reliable experimental measurements and mathematical analysis were employed to characterize applied potential effects on a culture of Saccharomyces cerevisiae. As inedited conclusions, it is reported that Power Spectrum Analyses is sensitive to growth phase at four particular frequencies. Furthermore, it was found that signal amplitude at such frequencies can be altered by potential application.

Oscillation on culture absorvance suggests modifications on population cell size. Cell size under applied potential, when observed through a microscope, decreased when compared to a control experiment. Cell viability, on the other hand, allowed suggesting that applied potential is able to trigger on or off cell cycle activity and, thus, force cell synchrony. In this sense, pulsed potential (or discontinuous electrochemical stress) promotes more severe changes on cell cycle. Mechanisms responsible for this biological response are yet to be investigated.

\section{ACKNOWLEDGEMENT}

The authors gratefully acknowledge FAPERJ and CNPq for financial support.

\section{RESUMO}

\section{Estimulação elétrica de células de Saccharomyces cerevisiae}

Modulação do potencial de membrana celular endógeno por um campo elétrico externo influencia a estrutura e função dos compartimentos da membrana, de suas proteínas e da bicamada lipídica. Neste trabalho, os efeitos da aplicação de potencial no crescimento de Saccharomyces cerevisiae foram caracterizados por experimentos simples, mas conclusivos. O perfil temporal de crescimento celular e a divisão celular foram investigados como respostas macroscópicas ao estímulo elétrico. Experimentos controle foram conduzidos em condições idênticas, exceto pela ausência de potencial aplicado. Através de análise comparativa, verificou-se que o estímulo elétrico alterou o ciclo celular como foi possível observar através da medida da dispersão de tamanho celular de cada população, sugerindo um possível sincronismo na divisão celular. Análise do espectro de potência foi empregada para sustentar o aumento no sincronismo, e uma modelagem matemática foi conduzida para determinar mudanças na cinética de crescimento celular. Parâmetros cinéticos do modelo tipo Monod para crescimento foram determinados por regressão não-linear. A constante de afinidade (a saber, $K_{S}$ ) apresentou uma dependência com o potencial aplicado, sugerindo mudanças no transporte através da membrana celular. Verificou-se, também, que o estresse promovido eletroquimicamente inibiu o crescimento e induziu mudanças na viabilidade celular.

Palavras-chave: estresse eletroquímico, Saccharomyces cerevisiae, ciclo celular, viabilidade 


\section{REFERENCES}

1. Bartlett, P.N.; Pletcher, D.; Zeng, J. Aprroaches to the integration of electrochemistry and biotechnology. J. Electrochem. Soc., 144 (11): 3705-370, 1997.

2. Becker, J.U. A method for glycogen determination in whole yeast cells. Anal. Biochem., 86: 56, 1978

3. Beschkov, V.N.; Peeva, L.G. Effects of electric current passing through the fermentation broth of a strain Acetobacter suboxydans Bioelectrochem. Bioenerg., 34: 185-188, 1994.

4. Binninger, D.M.; Ungvichian, V. Effects of $60 \mathrm{~Hz}$ AC magnetic fields on gene expression following exposure over multiple cell generations using Saccharomyces cerevisiae. Bioelectrochem. Bioenerg., 43: 83-89, 1997.

5. BSCS. 1983. Biological Science: Interaction of Experiments and Ideas. Englewood Cliffs, NJ: Prentice Hall.

6. Chen, W.; Han, Y.; Chen, Y.; Xie, J.T. Field-induced electroconformational damages in cell membrane proteins: a new mechanism involved in electrical injury. Bioelectrochem. Bioenerg., 47: 237 245, 1998.

7. Ci, Y.; Feng, J.; Jiang, Z.; Luo, D. The voltammetric behavior of Saccharomyces cerevisiae. Bioelectrochem. Bioenerg., 43: 293-296, 1997.

8. Fologea, D.; Vassu-Dimov, T.; Stica, I.; Csutak, O.; Radu, M. Increase of Sacchamoryces cerevisiae plating efficiency after treatment with bipolar eletric pulses. Bioelectrochem. Bioenerg., 46: 285 287, 1998.
9. Gheorghiu, E.; Asami, K. Monitoring cell cycle by impedance spectroscopy: experimental and theoretical aspects. Bioelectrochem. Bioenerg., 45: 139-143, 1998.

10. Goodman, R.; Blank, M. Magnetic field stress induces expression of hsp70. Cell Stress Chaperones, 3(2): 78, 1998.

11. Hjortso, M.A.A.; Nielsen, J. A conceptual model of autonomous oscillations in microbial cultures. Chem. Engng. Sci., 49(8): $1083-$ 1095, 1994.

12. Lötzbeyer, T.; Schuhmann, W.; Schmidt, H. Minizymes. A new strategy for the development of reagentless amperometric biosensors based on direct electron-transfer processes. Bioelectrochem. Bioenerg., 42: 1-6, 1996.

13. Münch, T.; Sonnleitner, B.; Fiechter, A. New insights into the synchronization mechanism with forced synchronous cultures of Saccharomyces cerevisiae. J. Biotechn., 24: 299-314, 1992.

14. Nakasono, S.; Matsumoto, N.; Saiki, H. Electrochemical cultivation of Thiobacillus ferrooxidans by potential control. Bioelectrochem. Bioenerg., 43: 61-66, 1997.

15. Peguin, S.; Soucaille, P. Modulation of metabolism of Clostridium aceyobutylicum in chemostat culture in a three-electrode potentiostatic system with nethyl viologen as electron carrier. Biotechnol. Bioengng., 51: 342, 1996.

16. Raabo, E.; Terkildsen, T.C. On the enzymatic determination of blood glucose. Scand. J. Clin. Lab. Invest., 12: 402, 1960.

17. Satroutdinov, A.D.; Kuriyama, H.; Kobayashi, H. Oscillatory metabolism of Saccharomyces cerevisiae in continuous culture. FEMS Microbiol. Lett., 98: 261-268, 1992. 